\title{
Кохичко А.Н. \\ Ценность как базовая категория аксиологического подхода к содержанию начального обучения русскому (родному) языку
}

Мурманский арктический государственный университет (Россия, Мурманск)

doi: $10.18411 / \mathrm{sr}-10-10-2017-10$

idsp: 000001:sr-10-10-2017-10

\section{Аннотация}

В статье в русле культурологического (культурно-исторического) и аксиологического подходов к содержанию образования осмысливается понятие «ценности», определяющей основное содержание духовно-нравственного развития и воспитания личности обучающихся в условиях реализации федеральных государственных образовательных стандартов второго поколения.

Ключевые слова: федеральный государственный образовательный стандарт, аксиологический подход к содержанию начального обучения русскому (родному) языку, ценность, «отношения» к миру,«проживание и осмысление» ценности.

В новых федеральных государственных образовательных стандартах в контексте культурологического (культурно-исторического) и аксиологического подходов к содержанию образования были определены цель, задачи, основные направления и ценностные ориентиры (основы) духовно-нравственного развития и воспитания обучающихся. Тем не менее, несмотря на многочисленную аксиологическую терминологию и весьма разнообразные ценности (системы ценностей), представленные в образовательных стандартах второго поколения, обращает на себя внимание отсутствие категории «ценность», определяющей основное содержание духовно-нравственного развития и воспитания личности обучающихся, в глоссариях «фундаментальных социальных и педагогических понятий» «Концепции духовно-нравственного развития и воспитания личности гражданина России» и «используемых понятий, обозначений и сокращений» «Основной образовательной программы образовательного учреждения».

Значимость и неопределенность «ценности» (Prezzo, Vale, Valeur, Valor, Value, Wert), одного из центральных понятий аксиологии, для наполнения конкретным содержанием современного образовательного процесса, русскому языку как родному в частности, потребовало нашего обращения к осмыслению данного понятия в различных аспектах научной мысли.

При традиционном разграничении материальных, духовных и культурных ценностей, В.Ф. Сержантов выделяет материальные (орудия и средства труда, вещи непосредственного потребления) и духовные (политические, правовые, моральные, эстетические, философские и религиозные идеи) ценности [15].

Н.А. Бердяев дефинирует духовные, социальные и материальные ценности[2, с. 171]. Сегодня в самом общем виде, как отмечает В.Л. Иванов, выделяются ценности материальные, духовные и социальные. В материальных ценностях, по мнению философа, «выражается отношение человека к вещам и процессам окружающего мира с точки зрения их способности удовлетворить его жизненно важные потребности <... Социальные ценности обеспечивают деятельность человека как социального существа. Наконец, благодаря духовным ценностям человек реализует себя как творческую и нравственную индивидуальность: созидает (и интерпретирует) художественные произведения, оценивает поведение окружающих и свое собственное и т. д.»[7, с. 4-5].

«В широком понимании в качестве ценности, - в изложении Е.С. Рапацевича, могут выступать не только абстрактные привлекательные смыслы или ситуативные ценности, но и стабильно важные для индивида конкретные материальные блага. В более узком значении принято говорить о ценностях как о духовных идеях, заключенных в 
понятиях, которые имеют высокую степень обобщения. Формируясь в сознании, эти ценности постигаются в ходе освоения культуры»[12, с. 659].

И все же, такие «общие» понимания ценности, по нашему мнению, не раскрывают сущности данной категории, о сложности и неоднозначности которой свидетельствуют и многочисленные подходы к ее классификации.

Так, М.И. Дьяченко и Л.А. Кандыбович, помимо материальных и духовных, разграничивают природные ценности.

Потребительную и меновую ценности находим у А. Мануилова.

В трактовке Э.Л. Радлова, «помимо субъективных ценностей, могут быть и общепризнанные ценности; к ним относятся этические, эстетические и экономические ценности».

«Двумя полюсами ценностного отношения человека к миру», констатирует О.Г. Дробницкий, являются предметные и субъектные ценности (ценности сознания, или ценности-представления)[4, с. 44-45; 6, с. 733]. При этом предметные ценности выступают как объекты ценностного отношения человека к миру. Субъектные ценности - выражение того же отношения со стороны субъекта, в которых интересы и потребности переведены на язык идеального, мыслимого и представляемого.Наряду с представленными выше, философом выделяются материальные и духовные, производственно-потребительские (утилитарные), социально-политические, познавательные, нравственные, эстетические и религиозные ценности[5, с. 462].

В.П. Тугаринов классифицирует ценности жизни и ценности культуры: материальные и духовные, группируемые на основе составляющих человека - тела и души - и социально-политические ценности. Отдельно философом выделяется группа конкретных ценностей[18, с. 23]. В другой систематике этого же автора находим ценности наличные (экзистенциальные), целевые и нормативные. Экзистенциальные ценности, в понимании В.П. Тугаринова, существуют во всех областях жизни и деятельности. К ним относятся все социально-политические и духовные ценности[17, с. 23-44].

Общечеловеческие, непреходящие, высшие ценности, которые сохраняют положительное значение во все времена и для всех людей и небольшую группу их антиподов (антиценностей) систематизирует С.Ф. Анисимов. При этом для обозначения ценностно-высшего философом группируются абсолютные (идеальные) и релятивные (относительные) ценности, обусловливаемые обстоятельствами места и времени, интересами, ценностными ориентациями людей[1, с. 43-44].

Для эмпирического исследования, позволяющего определить ценности общества в период кризиса, Н.И. Лапиным обозначены базовые ценности[9].

В.Н. Сагатовский[14], вычленяя ценностно-ориентационный аспект, объединяет ценности по различным видам деятельности: утилитарные; познавательные; управленческие; нравственные; эстетические; потребительские; творческие.

Д.А. Леонтьев разграничивает три формы существования ценности: общественный идеал, как выработанное общественным сознанием, содержащееся в нем абстрактное представление об атрибутах должного в различных сферах общественной жизни; предметное воплощение ценности, предстающее в объективированной форме в виде произведений материальной и духовной культуры либо человеческих поступков, и личностные ценности[10] и т. д.

Кроме того, в современной научной мысли мы находим ценности:

- витальные, социальные, политические, моральные, религиозные, эстетические;духовные - общечеловеческие, национальные, сословноклассовые, групповые, семейные, индивидуально-личностные (Н.Ф. Алефиренко);

- внутринаучные (когнитивные) (В.П. Кохановский);

- высшие (Б-ценности - бытия), низшие (Д-ценности - дефициентные) (А. Маслоу); 
- «дифференцирующие», «интегрирующие» (Н.И. Лапин);

- гуманитарного образования; кардинальные, субкардинальные, этосные (Н.С. Розов);

- жизненные (Е.А. Воронова);

- конкретно-исторические (В.Б. Шапарь, В.Е. Россоха, О.В. Шапарь);

- конкретные, абстрактные (К.А. Абульханова-Славская);

- конкретные жизненные - абстрактные, профессиональной самореализации - личной жизни, индивидуальные - межличностных отношений, активные - пассивные (Д.А. Леонтьев);

- личностные, общественные (Р.Н. Бунеев, Д.Д. Данилов, З.И. Курцева, Т.Д. Шапошникова, О.В. Чиндилова);

- малой родины, отечественные, родного очага, сугубо личностные (В.Т. Фоменко, И.Ю. Кулагина);

- материальные, духовные, культурные (В.Л. Абушенко, С.И. Ожегов, Н.Ю. Шведова);

- морального сознания (С.С. Аверинцев, И.С. Кон и др.);

- народной культуры (Г.И. Батурина, Т.Ф. Кузина);

- науки (В.А. Белов, В.П. Кохановский);

- общеродовые (М.Ю. Новицкая);

- объективно существующие, субъективно значимые (Я. Гудечек);

- основные национальные (Л.В. Трубайчук);

- официально признанные, осознаваемые (религиозные, гуманистические), действительные, бессознательные (порожденные социальной системой) (Э. Фромм);

- первичные, вторичные, третичные, несущественные (К. Ситерам, Г. Когделл);

- познания, политики, цивилизации, экзистенции, PR, церкви, социального действия, жизни (В.В. Ильин);

- смысла жизни; творчества, переживания, отношения (В. Франкл);

- целевые (мыслимые - желаемые, возможные), существующие (наличные актуальные);ценности-цели, ценности-идеалы, ценности-желания, ценности должного (нормативные) (В. Момов);

- ценности - цели, ценности - средства (М. Рокич);

- ценности-идеалы, ценности-свойства, ценности-способы поведения (С.С. Бубнова);

- этические - межличностного общения - профессиональной самореализации, индивидуалистические - конформистские - альтруистические, самоутверждения - принятия других, интеллектуальные непосредственно-эмоционального мироощущения (Д.А. Леонтьев) и др.

На основании изложенного выше можно сделать вывод о том, что однозначно определить сферу действительности, обозначаемую понятием «ценность», чрезвычайно сложно. Тем не менее, несмотря на различные многочисленные: информационные (В.И. Першиков, В.М. Савинков и др.); культурологические (М.Б. Ладыгин, О.М. Ладыгина и др.); педагогические (Е.В. Бондаревская, Р.Н. Бунеев, Д.Д. Данилов, З.И. Курцева, Т.Д. Шапошникова, О.В. Чиндилова; Е.А. Воронова, В.А. Караковский, А.В. Кирьякова, З.И. Равкин, Е.С. Рапацевич, В.Т. Фоменко, И.Ю. Кулагина, Н.Е. Щуркова и др.); политологические (Ю.И. Аверьянов и др.); психологические (М.И. Дьяченко, Л.А. Кандыбович; М.И. Еникеев, Л.А. Карпенко, И.М. Кондаков, Р.С. Немов, В.Б. Шапарь, В.Е. Россоха, О.В. Шапарь и др.); социологические (А.С. Айзикович, Г.М. Андреева, В.И. Антонюк; Н. Аберкромби, С. Хилл, Б. Тернер; Г.В. Осипов и др.); философские (А.К. Абишева, С.Ф. Анисимов, Н.А. Бердяев, О.Г. Дробницкий, Е.В. Золотухина-Аболина, В.Л. Иванов, Д.А. Леонтьев, А. Мануилов, С.Я. Матвеева, В.Н. Сагатовский, В.П. Тугаринов, С.Л. Франк, И.Т. Фролов и др.); экономические (Б. Берман, Дж. Эванс; М.Б. Вуд, П.Р. Палажченко, Б.А. Райзберг, Л.Ш. Лозовский, Е.Б. Стародубцева и др.); эстетические (М.Ф. Овсянников, 
В.А. Разумный и др.); этические (С.С. Аверинцев, А.В. Адо, М.И. Андриевская и др.); этнопсихологические (В.Г. Крысько, Э.А. Саракуев) и другие представления о ценности, мы в рамках аксиологического подхода к обучению русскому (родному) языку можем обозначить следующие положения:

1. В качестве ценности могут выступать различные сферы действительности (окружающего, внешнего мира): объекты, предметы, явления (стороны, свойства предметов и явлений) природы и общества; (формы проявления) отношения между субъектом и объектом (отношение человека к вещам и процессам окружающего мира; все многообразие общественных отношений); (идеальные) представления о предпочитаемых благах и способах их получения; момент значимости одного явления для бытия другого; идеи и побуждения; установки и оценки, императивы и запреты, цели и проекты, выраженные в форме нормативных представлений; способы и критерии оценивания соответствующих явлений; способы и критерии оценок и предписания объектов; предпочтение личностью или обществом определенного образа поведения или конечного состояния; целеполагающая деятельность человека, поведение окружающих и свое собственное и др.

2. Существенными признаками (качествами, свойствами, особенностями, спецификами) ценности являются: полезность, нужность людям (определенного общества, класса, отдельной личности); (человеческая, социальная, культурная, хозяйственная) значимость (для человека, класса, группы, общества в целом) какого-либо объекта; нормативность, предписательно-оценочная сторона явлений общественного сознания; концентрирование предшествующего опыта субъекта; целеполагание деятельности людей, определение образа поведения или конечного состояния и др.

3. Функциональные предназначения ценности заключаются в том, чтобы: быть полезной, нужной, удовлетворять какие-либо (определенные, жизненно важные, хозяйственные) потребности (стремления, интересы, цели)человека, класса, общества; выступать мерой зависимости одного явления от другого; быть для людей действительностью, нормой, целью, идеалом, (повседневным) ориентиром (направленностью) поведения и деятельности (в предметной и социальной действительности); быть основанием целеполагающей деятельности людей, определять образ поведения или конечного состояния, в противоположность другому типу поведения или состоянию, обеспечивать деятельность человека как социального существа, выступать для индивида (субъекта) внутренним и внешним (общественным) регулятивом его отношений с миром; реализовывать себя как творческую и нравственную индивидуальность; активно и сознательно преобразовывать мир и самого себя в соответствии со значимыми для себя идеальными представлениями и др.

Несомненно, многочисленные и разнообразные классификации ценностей имеют большое значение для понимания природы ценностей, осмысления личностного, социального и культурного значения определенных явлений действительности, отношений между субъектом и объектом, расширения границ познания универсальной взаимозависимости явлений. Тем не менее, как отмечает В.К. Шохин, сегодня область аксиологии, «охватывает применение понятия «ценность» и прилагательного «ценностный» ко всем практически сферам человеческого познания и деятельности (от политики до медицины), а потому закономерно ведет к «обесцениванию ценностей» как глубинно-личностных атомов человеческой экзистенции и создает кризис в аксиологии, преодолимый только серьезными «антиинфляционными» мерами, связанными в первую очередь с «лечением» самого современного языка и серьезной работой над категориями аксиологии»[21, с. 24-25].

Соглашаясь с рассуждениями В.К. Шохина, считаем чрезвычайно важным для формирования национального (этнического) самоопределения младших школьников при обучении русскому (родному) языку, определиться с изначальной методологической дефиницией центрального понятия теории ценностей, обратившись при этом к русскому 
языку и философскому пониманию «ценности» как базовой категории аксиологии. Анализ содержания представлений о ценности позволит установить, что именно обозначается этим словом, каким комплексом качеств характеризуется данная категория, и какие функции она выполняет.

Согласно Э.Л. Радлову[19, с. 265], под ценностью, понимается «результат оценки, т. е. определение отношения известного объекта к стремлению, потребности или целям человека. Объект имеет ценность, поскольку он служит к удовлетворению стремлений и целей. Таким образом, вне области стремлений нет ценностей».

«Категория ценности, - в изложении В.А. Василенко, - раскрывает один из существенных моментов универсальной взаимозависимости явлений, а именно момент значимости одного явления для бытия другого»[3, с. 42].

В.П. Тугаринов $[16$, с. 276]трактует ценности как «суть предмета, явления и их свойства, которые нужны людям определенного общества или класса и отдельной личности в качестве средств удовлетворения их потребностей и интересов, а также - идеи и побуждения».

Ценности, подчеркивается в «Кратком словаре по философии» под общей редакцией И.В. Блауберга, И.К. Пантина, - «явления как материального, так и духовного характера, обладающие положительной значимостью, т.е. способные удовлетворять какие-либо потребности человека, класса, общества, служить их интересам и целям»[8, с. $381]$.

Как «специфически социальные определения объектов окружающего мира, выявляющие их положительное или отрицательное значение для человека и общества» истолковываются ценности в «Философском словаре» под редакцией И.Т. Фролова. «По отношению к субъекту (человеку), - находим далее, - ценности служат объектами его интересов, а для его сознания выполняют роль повседневных ориентиров в предметной и социальной действительности, обозначений его различных практических отношений к окружающим предметам и явлениям»[20, с. 534].

«По существу, - подытоживает О.Г. Дробницкий[6], - всё многообразие предметов человеческой деятельности, общественных отношений и включенных в их круг природных явлений может выступать в качестве «предметных ценностей» как объектов ценностного отношения, т. е. оцениваться в плане добра и зла, истины или неистины, красоты или безобразия, допустимого или запретного, справедливого или несправедливого» и т. д.».

Если «в обыденном сознании и обычном словоупотреблении, - замечает С.Ф. Анисимов, - под ценностями чаще всего подразумевают предметы, обладающие какиминибудь полезными для человека свойствами», то «в философии понятие ценности имеет более отвлеченный смысл, близкий к понятию «значение», <..> положительное значение данного предмета или его свойства для конкретного субъекта деятельности (индивида, класса, общества) с точки зрения того, насколько этот предмет способен удовлетворять определенную потребность. Поэтому, - продолжает философ, - можно сказать, что понятие ценности отражает не столько сам факт возникновения ценностного отношения между предметом и потребностью в нем, сколько определенное качество этого отношения (выделено нами), которое и фиксируется в сознании в виде суждения об этом качестве оценки»[1, с. 40]. При этом под отношением между человеком и миром в истории и современной лексике русского языка понимается:

1. Составление своего представления о ком-либо, чем-либо, внутреннее оценивание, проявление своего чувства по отношению к кому-либо, чему-либо, симпатии или антипатии; принятие чего-либо каким-либо образом. [Лариса] Поддержите меня, мне нужно одобрение, сочувствие; отнеситесь ко мне нежно, с лаской! А. Островский. Плотник весь напрягся и внимательно слушал, разиня рот. Он не знал, как отнестись к этой речи, - верить ей или смеяться над нею? С. Скиталец. 
2. Взаимная связь, зависимость разных величин, предметов, действий, явлений, соотношение между чем-либо. Если взять наличную массу каторжных за все время ее пребывания на острове, то отношение бегавших в разное время к общему составу выразится не менее, как в шестидесяти процентах. А. Чехов.

3. Тот или иной характер поведения, обращения кого-либо с кем-либо, чемлибо. Один из моих товарищей-экспертов обратил мое внимание на грубое отношение прокурора к подсудимым. А. Чехов.

4. Взгляд на что-либо, восприятие, понимание чего-либо. Трудно во всемирной литературе найти двух художников, у которых отношение к жизни было бы до такой степени противоположно, как у Толстого и у Достоевского. В. Вересаев.

5. Связи между кем-либо, чем-либо, образующиеся в процессе общения, при контактах, какой-либо деятельности . Дома́ Левиных и Щербацких были старые дворянские московские дома и всегда были между собою в близких и дружеских отношениях. Л. Толстой.

6. Причастность к чему-либо, связь с кем-либо, чем-либо; принадлежность, касательство. Мы растрату рассматриваем, так сказать, теоретически, без всякого отношения к личностям. Н. Островский.

7. Отдельная сторона, точка зрения, аспект. В композиционном отношении доклад проигрывает всем прочим.

8. Деловая, служебная бумага с запросом или уведомлением о чем-либо. Несколько занумерованных отношений и предписаний полетело в разные стороны. И. Тургенев. Из готового уже дела велено было ему сделать какое-то отношение в другое присутственное место. Н. Гоголь[Даль В.И., Евгеньева А.П., Ожегов С.И., Стоян П.Е., Ушаков Д.Н.,Шведова Н.Ю.] и др.

Приняв за основу базовое (первое) истолкование «отношения», можно констатировать, что ценность, «в целостной структуре мироотношения и мировоззрения людей» (в аксиологическом определении В.П. Плотникова[13, с. 196] - категория, возникающая в результате «внутреннего оценивания» (природа ценности) и способствующая мотивации поступков и действий человека (место и роль ценности). Объединяющим «мироотношения и мировоззрения людей» является «смысл».

Делая обобщение, согласимся с утверждением Н.О. Лосского о том, что ценность «есть нечто всепроникающее, определяющее смысл и всего мира в целом, и каждой личности, и каждого события, и каждого поступка. Всякое малейшее изменение, вносимое в мир каким бы то ни было деятелем, - отмечает философ, - имеет ценностную сторону и предпринимается не иначе как на основе каких-либо ценностных моментов и ради них»[11, с. 7]. Осмысление ценности, как смысла мы находим и в многочисленной научной мысли (Б. Г. Ананьев, Н.А. Бердяев, Б.С. Братусь, Г.Л. Будинайте, Т.В. Корнилова, Я. Гудечек, М.И. Еникеев, Е.А. Климов, В.Е. Клочко, Б.С. Круглов, Д.А. Леонтьев, А.А. Леонтьев, В.С. Мухина, И.Г. Петров, Е.С. Рапацевич, В.Н. Сагатовский, А.В. Серый, С.Л. Франк, В. Франкл, Н.Л. Худякова, М.С. Яницкий и др.).

Для методологических основ формирования национального (этнического) самоопределения младших школьников при обучении русскому языку как родному, особое значение приобретает то обстоятельство, что связь ценности со смысловой сферой личности не противоречит современной парадигме личностно развивающего образования, определяющей своеобразие подхода, который применяется в начальном образовании (И.В. Абакумова, К.А. Абульханова-Славская, Н.А. Алексеев, Ш.А. Амонашвили, А.Г. Асмолов, В.А. Беликов, М.Н. Берулава, Л.И. Божович, Е.В. Бондаревская, С.К. Бондырева, Р.Н. Бунеев, Р.Н. Бунеева, О.С. Газман, В.В. Давыдов, Л.В. Занков, И.А. Зимняя, В.П. Зинченко, Е.Б. Моргунов, Т.Г. Калугина, В.Е. Клочко, Г.Б. Корнетов, Е.А. Крюкова, А.А. Леонтьев, В.Э. Мильман, Н.Д. Никандров, В.В. Рубцов, А.В. Петровский, В.Н. Сагатовский, В.В. Сериков, Г.Н. Сериков, В.И. Слободчиков, Л.В. Трубайчук, Д.И. Фельдштейн, Е.Н. Шиянов, Д.Б. Эльконин, И.С. Якиманская, Е.А. Ямбург и др.). 
Отличительной особенностью данного подхода «является направленность на формирование мотивационно-смысловой стороны учебной деятельности», которая «трансформируется из присвоения социокультурного опыта в процесс саморазвития личности». При этом смыслообразующая деятельность учащихся как обогащение структур сознания и выход за пределы собственного «Я» обеспечивается созданием образовательных пространств разного уровня (урок как микропространство, исследовательская деятельность учащихся вне урока, дистанционное обучение), а содержание обучения рассматривается как «субстрат, питающий смысловое развитие учащихся» (И.В. Абакумова). Средствами обучения, включающего процессы смыслообразования, смыслопорождения и смыслотворчества, выступают смыслы и их формы (переживания, саморефлексия, интроекция, творческие акты).

Подводя итог, отметим, что в качестве ценности выступает мыслительный образсубъекта (индивида и общества (класс, группа, слой, этнос и др.), в котором фиксируется отношение этого субъекта с какими-либо объектами. Основу этой связи составляет то, что объект переживается («проживается») субъектом как необходимый, значимый, имеющий смысл для субъекта.

Данное понимание ценности должно способствовать организации эмоциональноценностного процесса обучения русскому языку как родному в русле культурологического (культурно-исторического) и аксиологического подходов к содержанию образования через «отношения» к миру, его непосредственное «проживание», который, по точному замечанию А.А. Леонтьева, обучающийся«переживает и осмысляет для себя».

$$
* * *
$$

1. Анисимов, С.Ф. Духовные ценности : производство и потребление [Текст] / С.Ф. Анисимов. - М. : Мысль, 1988. - 253 с.

2. Бердяев, Н.А. Судьба России : Опыты по психологии войны и на-цио ᄀнальности [Текст] / Н.А. Бердяев. - М. : Мысль, 1990. - 208 с.

3. Василенко, А.В. Ценность и ценностные отношения [Текст] / А.В. Василенко // Проблемы ценности в философии. - Л. : Наука, АН СССР, 1966. - С. 44-98.

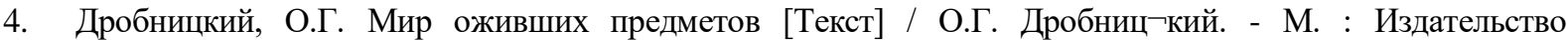
политической литературы, 1967. - 351 с.

5. Дробницкий, О.Г. Ценность [Текст] / О.Г. Дробницкий // Философ-ская энциклопедия : в 5 т. / гл. ред. Ф.В. Константинов. - М. : Со-ветская эн-циклопедия, 1960-1970. Т. 5. - С. 462-463.

6. Дробницкий, О.Г. Ценность / [Текст] / О.Г. Дробницкий // Философ ский энциклопедический словарь / редкол. : С.С. Аверинцев, Э.А. Араб-Оглы, Л.Ф. Ильичев и др. - 2-е изд. - М. : Советская энциклопедия, 1989. - С. 732-733.

7. Иванов, В.Л. Аксиология [Текст] / В.Л. Иванов // Словарь философских терминов / научн. ред. проф. В.Г. Кузнецов. - М. : ИНФРА-М, 2007. - С. 4-6.

8. Краткий словарь по философии [Текст] / под общ. ред. И.В. Блауберга, И.К. Пантина. - 4-е изд. - М. : Политиздат, 1982. - 431 с.

9. Лапин, Н.И. Модернизация базовых ценностей россиян [Текст] / Н.И. Лапин // Социологические исследования. - 1996. - № 5. - С. 3-23.

10. Леонтьев, Д.А. Ценность как дисциплинарное понятие многомерной реконструкции [Текст] / Д.А. Леонтьев // Вопросы философии. - 1996. - № 3. - С. 15-25.

11. Лосский, Н.О. Ценность и бытие : Бог и Царство Божие как основа ценностей [Текст] / Н.О. Лосский. Харьков : Фолио; М. : ООО «Фирма «Издательство АСТ», 2000. - 864 с.

12. Педагогика : Большая современная энциклопедия [Текст] / сост. Е.С. Рапацевич. - Мн. : Современное слово, 2005. $-720 \mathrm{c}$.

13. Плотников, В.И. Ценностный мир человека и его судьба [Текст] / В.И. Плотников // Двенадцать лекций по философии. - Екатеринбург : Изд-во Уральской государственной юридической академии. - 1996. C. $193-224$.

14. Сагатовский, В.Н. Системный подход к классификации ценностей [Текст] / В.Н. Сагатовский // Научные исследования и человеческие потребности. Материалы к симпозиуму ЮНЕСКО. - М. : ВНИИ системных исследований, 1979. - 119 с.

15. Сержантов, В.Ф. Человек, его природа и смысл бытия [Текст] / В.Ф. Сержантов. - Л. : Изд-во Ленинградского ун-та, 1990. - 360 с. 
16. Тугаринов, В.П. Избранные философские труды [Текст] / В.П. Тугаринов / предисл. А.О. Бороноева : ЛГУ им. А.А. Жданова. - Л., 1988. - 343 с.

17. Тугаринов, В.П. Соотношение категорий диалектического материа-лизма [Текст] / В.П. Тугаринов. - Л. : Изд-во Ленинград. гос. ун-та, 1956. - 122 с.

18. Тугаринов, В.П. Теория ценностей в марксизме [Текст] / В.П. Туга-ри ᄀнов. - Л. : Изд-во Ленинград. гос. ун-та, 1968. - 124 с.

19. Философскій словарь логики, психологіи, эстетики и исторіи философіи [Текст] / подь ред. Э.Л. Радлова. - С.-Петербургъ, 1911. - 284 с.

20. Философский словарь [Текст] / под ред. И.Т. Фролова. - 5-е изд. - М. : Издательство политической литературы, 1986. - 590 с.

21. Шохин, В.К. Аксиология [Текст] / В.К. Шохин // Философия : энциклопедический словарь / под ред. А.А. Ивина. - М. : Гардарики, 2006. - С. 22-25.

Тарасенко Н.Г.

Методологические основы формирования онтологической составляющей глобально-ориентированного мировоззрения личности в современном образовательном процессе

Белгородский государственньй научно-исследовательский университет doi: $10.18411 /$ sr-10-10-2017-11

(Россия, Белгород)

idsp: 000001:sr-10-10-2017-11

\section{Аннотация}

В статье акцентируется внимание на глобализации как тенденции развития современной цивилизации, обусловливающей необходимость формирования глобальноориентированного мировоззрения личности. Автор аргументирует точку зрения, в соответствии с которой в роли методологической основы нового типа мировоззрения в целом и его онтологической составляющей, в частности, способны выступить глобальные идеи философии космизма. В статье раскрывается сущностное содержание этих идей и определяются соответствующие блоки знаний содержания образования, нацеленного на формирование онтологической составляющей глобально-ориентированного мировоззрения личности.

Ключевые слова: глобализация; глобально-ориентированное мировоззрение личности; онтологическая составляющая мировоззрения; философия космизма; методологическая основа; картина мира; образовательный процесс

Совершенствование общества XXI века связывается с образовательной парадигмой, отвечающей тенденциям развития мировой цивилизации. Формирование востребованного временем мировоззрения личности исконно является основополагающей задачей педагогики и системы образования.

Общепризнан вывод современных учёных о том, что объективной и приоритетной по степени значимости характеристикой современного этапа развития человечества является глобальность (Э.В. Гирусов, В.И. Данилов-Данильян, Г.В. Номеровская, А.Л. Пастухов, А.Л. Романович и др.). В XXI веке глобализация представляет собой главный фактор развития человечества как планетарного единства. С внешней объективной стороны происходит глобализация земных связей человека. Поскольку именно человек в конечном итоге творит глобальный мир, то появляется необходимость глобализации сознания человека. Следовательно, формирование отвечающего вызовам времени мировоззрения личности предполагает отражение в образовательном процессе глобальных тенденций мирового развития.

Для педагогической науки важно понимание того, каким образом внешняя глобализация как объективный процесс сопряжена с её субъективной стороной мировоззрением личности. Приоритетная задача педагогической науки состоит в том, 